\title{
Limiting the executive power after the Second World War: the invention of administrative science
}

Céline Mavrot ${ }^{1,2}$

${ }^{1}$ University of California - Los Angeles (UCLA), ${ }^{2}$ KPM Center for Public Management, University of Bern

Pre-Layout/Pre-Print Version - This is not the latest version, please refer to:

Mavrot Céline (2021). "Limiting the executive power after the Second World War: the invention of administrative science", International Review of Administrative Sciences, early online. DOI: 10.1177/0020852320985591

\begin{abstract}
This article analyses the emergence of an administrative science in France in the wake of World War II. The birth of this discipline is examined through the history of its founders, a group of comparatists aiming at developing universal administrative principles. The post-war context prompted the creation of checks and balances against administrative power (oversight of the legality of administrative action), and against the powers of nation states (human rights and international organisations). Administrative science and comparative law were meant to rebuild international relations. The history of this discipline highlights a legal project to redefine the role and limits of executive power at the dawn of the construction of a new world order.

\section{Points for practitioners}

Looking at long-term developments in the science of administration helps to inform administrative practice by providing a historical and reflective perspective. This article shows how a new understanding of the administrative reality emerged after the fall of the totalitarian regimes of the first half of the 20th century. It highlights the different ways in which administrative power was controlled after the World War II through greater oversight over administrative legality, the establishment of universal administrative principles and the proclamation of human rights. Questions of administrative legitimacy and limitation of administrative power still are very much part of the daily practice of the executive power, and represent a central aspect of administrative thinking.
\end{abstract}

Keywords: administrative science, administrative law, comparative law, history of law, International Institute of Administrative Sciences (IIAS), France, pacifism, World War II

\section{Introduction}

Little attention has been given to date to the creation of a French administrative science in the aftermath of World War II. In the immediate post-war period, a group of comparative lawyers created a new scientific discipline under this name. In a country strongly marked by a tradition of administrative law, this initiative was by no means insignificant. Taken up by jurists with a strong internationalist vision, this new science was immediately conceived as a supranational instrument at the service of peace. It aimed not only to strengthen the control of administrative activity, but also to 
bring nations together around universal administrative principles. This endeavour was part of a more general context aimed at renewing the constitutional order as well as the understanding of the administrative reality in the post-war period. On the one hand, the post-World War II period was a time of intense reflection on the legitimacy of the administration (Baruch and Duclert, 2003) accompanied by major administrative reform projects (Payre, 2002: 543). On the other hand, administrative law came under criticism for its inability to account for the increasing complexity of administrative phenomena (Chevallier, 1986: 36-37). The intention of the founders of administrative science was to analyse administration in the light of sociological concepts, taking it beyond a purely legal framework of analysis.

Their initiative was also deeply affected by the two world wars witnessed by this generation, prompting them to conceptualize checks and balances mechanisms against authoritarian excesses. While the immediate post-war period spawned a number of cultural, diplomatic, economic and intellectual initiatives aimed at restoring international dialogue, French administrative science made its contribution to the legal side of this movement. The comparatism that underlies it was conceived as an instrument of dialogue between nations. This example underlines the importance of understanding emerging knowledge in the 'disciplinary configuration' from which they come, at the interplay between various disciplines (Blondiaux, 2002: 58). In this case, comparative administrative law was given a new momentum in the post-war period. Through administrative science, it was to contribute to the reflection on how to limit national sovereignty and the executive power-via human rights, international organisations, guarantees relating to administrative legality-in the wake of the trauma of war, and in order to restore a peaceful world order (Mavrot, 2015; Sager et al., 2018).

This article traces the creation of administrative science by its pioneer generation, looking back at the history of three of its founders: René Cassin, Roland Drago and Georges Langrod. It aims at understanding the content but also the ambiguities of this project of comparative science with a universal ambition. These authors were the most active promoters of an administrative science, not only through their writing and teaching activities, but through their participation in international bodies of administrative studies. Beyond the French case, the history of this discipline reveals a changing context for the production of knowledge on administration and significant shifts in the types of administrative legitimacy. Highlighting this founding moment thus makes it possible to take a new look at the history of administrative thinking, both French and international.

\section{Theoretical framework}

Administrative science was created in a historical context generating specific types of knowledge production (Ihl et al., 2003). The dominance of the legal approach to administration constitutes its main characteristic. We examine how "the historical process of division of labour leads to new [disciplinary] specializations and pairings between [scholarly] groups and research objects" (Fabiani, 2006: 28). We explore what distinguishes French authors of administrative science from other law scholars through the lenses of the disciplinary context, as a meso level of analysis. The authors' trajectories are also taken into account. This micro-focus allows us to understand this new science in the light of the aims of its proponents (Pinto, 1995: 8-9): a renewal of administrative studies, the promotion of comparatism and the establishment of a legal dialogue in the post-war context. 


\section{Administrative science as a blind spot in the history of disciplines}

The history of administrative science remains largely unknown. The most comprehensive analysis is provided by Jacques Chevallier (1986: 27-50), who offers an overview from the 17th century to the contemporary period. The author underlines the dominance of the legal approach, as well as the widespread focus on the jurisdictional oversight of the administration since the end of the 19th century (Chevallier, 1986: 32). From that time on, the Council of State (Conseil d'État) gained scientific legitimacy for formulating administrative law, which became the main analytical framework for interpreting administrative action (Vanneuville, 2003). The existence of government sciences (sciences de gouvernement) around the 18th and 19th centuries, prior to administrative law, has also been studied. As 'policy engineering', their main function was to support government practices (Ihl and Kaluszynski, 2002: 4, 233). However, the subsequent development of administrative law explains the legal tendency of contemporary French administrative science (Mavrot, 2015).

There are also studies on selected aspects of the history of administrative science. Renaud Payre (2006) looked at the creation of a transnational networks of administrative science around the International Institute of Administrative Sciences (IIAS) during the inter-war period. Pierre-Yves Saunier (2004) analysed how French academia discovered the American Public Administration in the context of American philanthropic programmes. A history of the emergence of French administrative science from the immediate post-war period remains to be written, however. Unlike the United States, where Public Administration has been a scientific discipline in its own right since the first decades of the 20th century (Saunier, 2003), French administrative science has struggled to establish its own scientific foundations.

\section{Body of sources and methodology}

The article is based on a body of primary sources constituted by the writings of the founders of French administrative science from the immediate post-war period-when this it was created-until the 1980s, when all mention of this science disappeared in the academic world. Most of the sources are from the fifties and sixties, the golden age of this scientific project. The body of sources includes the textbooks of these authors as well as their contributions in journals. The articles have been selected through a keyword search of the Persée database, which includes all issues of numerous public law journals, in particular the Revue internationale de droit comparé (journal of the Paris-based Society of Comparative Legislation - Société de Législation Comparée (SLC)). A complementary search of the Gallica database of the Bibliothèque nationale de France additionally led to a complete analysis of the Cahiers de l'Institut français des sciences administratives (IFSA). Finally, the International Journal of Administrative Sciences (IIAS journal) was also part of the corpus.

This study is based on a qualitative documentary analysis of these sources. The theoretical approacha socio-history of government sciences (Ihl et al., 2003)-has two methodological repercussions. On the one hand, to avoid any predefinition of the object, the scope of the investigation field was not determined in advance. The analysis shows that administrative science was created by individuals located at various positions and perspectives within the administrativist space, and was not a unified project. We therefore analysed the genesis of this discipline inductively, in the different arenas where this knowledge emerged. On the other hand, to go beyond the limits of a monographic approach restricted to a national perspective, the birth of French administrative science is interpreted in the context of its international connections. Thus, the body of data includes material relating to 
supranational scholarly arenas, and the creation of French administrative science is interpreted in the light of the debates taking place there.

\section{The emergence of French administrative science after the war}

\section{Administrative science: scientific objects and concepts}

Whereas the expression "administrative science" was rare in France until the 1940s, a few authors popularized this label in the immediate post-war period. These authors were either members of the Court of Auditors (Cour des comptes), such as Bernard Gournay, of the Council of State, such as René Cassin, Henry Puget and Guy Braibant, as well as law professors, such as Charles Debbasch, Roland Drago and Georges Langrod. In the course of their jurisdictional or doctrinal activities, they were looking for new ways to control the administration ${ }^{1}$. In this context, they perceived administrative science as useful to the administrative courts, in particular in reviewing the grounds of administrative acts (Druesne, 1978: 916). For these authors, "administrative law is a normative discipline" based on "deductive reasoning", whereas "administrative science is a positive discipline": "It is essentially concerned with the way the law is applied" (Gournay, 1966: 8). This raises the question of "what the administration is, what it should be, what it will be", in order to "learn lessons from the field that will lead to the desired changes" (Debbasch, 1972: 7). These authors take a close interest in the legality of administrative action, particularly with regard to the protection of citizens (Braibant et al., 1973), administrative oversight (Debbasch, 1978), the supervision of administrative decisions (Gournay, 1962), or the administration's relations with international organisations (Puget, 1951).

Another common feature of the founders of administrative science, except for Gournay, is that they were all comparatists, which goes together with an international openness. Most of them contributed to the work of the Society of Comparative Legislation, a centre for the study of the comparative method. Puget was its vice-president (Cassin, 1967: 488), while Cassin (1952-1954) and Drago (19791983 ) both served as its president. The SLC is a scholarly society founded in 1869 , and compares various legal solutions to similar problems around the world. It brings together legal practitioners and theorists from different countries. It coordinates many international works, and is also a documentation centre (Drago, 1969c). The intellectual core of the SLC thus matches the French administrative science project. To understand the true nature of administrative phenomena in their context, administrative science has to bring together law and sociology (Langrod, 1952: 29). Comparatism is therefore consistent administrative science, which is concerned with empirical reality: "The need to go beyond the nationalism of administrative law studies had already been felt (...). This nationalism is even more questionable in administrative science, where systems are more important than positive law" (Debbasch, 1970): 436). Rather than an administrative law restricted to the national doctrine, these authors called for the comparative study of administrative systems.

With the label "administrative science", the authors underlined the need to study the reality in which the rule of law is embedded: administrative procedures, the organisation and functioning of services, the administrative climate. While this sociological openness might seem heterodox, it is rooted in the emerging discourses in the scientific disciplines related to administrative law. The study of administration was opening towards the social sciences. This shift in scientific boundaries also

\footnotetext{
${ }^{1}$ The sciences of government constituting "a support for the rationalisation and control of politico-administrative practices" (Payre and Vanneuville, 2003: 198).
} 
considerably changed the perspectives in the field of law. The idea was to move beyond analyses exclusively focused on the formal rule, at a time when law was strongly criticized by the social sciences-particularly the sociology of organisations (e.g., Crozier 1979), which had built its approach to administration in opposition to law. Because of their interest in foreign administrative systems as well as the litigations reviewed by administrative courts, comparatists and members of the Council of State-the founders of the administrative science project-were more likely to be open to criticism against law than their peers, who were more focused on national law and on legal exegesis.

\section{Institutionalising administrative science: diffusion supports and venues}

The first founding acts included the production of compendiums, bibliographies and textbooks, providing the basis of a scientific know-how for administrative science. Langrod coordinated the Traité de science administrative (Auby et al., 1966), bringing together the contributions of 46 authors in order to lay the theoretical foundations of the discipline in France. During the same period, other textbooks were published: Introduction à la science administrative (Gournay, 1966) and Science administrative : administration publique (Debbasch, 1972). Drago created two collections in 1969: La bibliothèque de science administrative (Librairie Générale de Droit et de Jurisprudence), which publishes theses, as well as the Science administrative series (Armand Colin). Langrod also imported foreign models by publishing La science et l'enseignement de l'administration publique aux États-Unis in 1954, followed by Puget who published in 1961 an Essai de bibliographie des principaux ouvrages de droit public (...), de science politique et de science administrative qui ont paru hors de France de 1945 à 1958. These founding publications were addressed to their peers, with the idea to found a new discipline, as well as to a student audience, to establish a new research tradition on administration.

To promote their ideas, these authors quickly created institutional supports to publicise, shape and legitimise this discipline. Puget headed the Centre de Recherches Administratives (CRA) from its creation in 1946 within the Fondation nationale des sciences politiques (FNSP). The centre studies administrative structures, with a focus on foreign examples. Later to become the CEVIPOF (Centre de recherches politiques de Sciences $P$ o), the CRA was one of the few French research centres focusing on public administration as its exclusive research topic (Sadran, 1999: 148). The CRA collaborated closely with the IIAS, and also served as secretariat to the IFSA (Puget, 1950: 107-8)-the latter being based within the Council of State. These authors also set up teaching programs, although few academic positions were specifically dedicated to administrative science. Drago held the chair of administrative science created at the Faculty of Law in Paris in 1965 (Braibant, 1969: 6), and created the Centre d'Études et de Recherches de Sciences Administratives (CERSA) at the Université Panthéon-Assas at the end of the 1960s. Langrod taught administrative science in the 6th section of the École Pratique des Hautes Études (EPHE) between 1962 and 1975 (Boulet et al., 1980: 464). Institutionally, administrative science was therefore linked to practitioners' organisations (Council of State), to international platforms (IIAS and its French section), and to academic centres, attached to those who held positions there (Law Faculties, EPHE, FNSP).

The authors of French administrative science were actively involved in international academic arenas. Most of them took part in the activities of the IIAS. The IIAS, an international scientific organisation founded in 1930, federates member states throughout the world around research on administration. ${ }^{2}$ Cassin was appointed vice-president of the IIAS in 1949, and Puget chaired its scientific commission for

\footnotetext{
${ }^{2}$ https://www.iias-iisa.org/page/ABOUT\%20IIAS?lang=fr
} 
twenty years from that same date (Payre, 2006: 655-656). Braibant was its general director (19791981) and then its president (1988-1992) (Timsit, 2008: 368). Some of these authors also participated in the work of another crucial international platform in the post-war period, the United Nations Educational, Scientific and Cultural Organization (UNESCO). UNESCO played a leading role in the international development of social sciences, through the establishment of editorial or institutional support; it initiated the creation of the International Political Science Association in 1949 (Gottraux et al., 2004: 3). Cassin was the French delegate to the international conference that led to the creation of UNESCO in 1944, and Puget chaired its Appeals Board for eighteen years (Cassin, 1967: 487). Langrod wrote a chapter of the international political science textbook published by UNESCO in 1950 (Langrod, 1950). As for Drago, he was a member of the French delegation to its General Conference in 1980 (Sager et al., 2018: 109-110).

The French authors discovered different foreign models of administrative science through these international platforms. Referring to a UNESCO report, written in collaboration with IIAS, on the study and teaching of Public Administration, Langrod pointed out:

"The reader is thus able to appreciate the very important broadening of perspectives (...) that is administrative science. For the jurist in general, and for the comparatist in particular, this process is of major importance. Understanding the merits of a non-legal study of public administration (...) significantly broadens our scientific perspectives" (Langrod, 1959: 620-21).

Given the diversity of national legal systems, comparatists compare phenomena which, depending on the context, are either legal or extra-legal. They cannot therefore be satisfied with the demarcations made by administrative law. Administrative science provides the comparatist with the tools to integrate infra-legal phenomena into the analysis (Langrod, 1960: 55). It gives jurists access to a nonnormative knowledge of the administration as a "sociological environment", in order to better control it (Drago, 1969a: 12-13, 17). The supranational engagements of these authors finally were in line with a broader humanist project. After serving as the French delegate to the United Nations Commission for the Investigation of War Crimes between 1943 and 1945, Cassin dedicated his career to human rights. In 1947, he initiated the creation of the National Consultative Commission on Human Rights in France. Braibant was appointed a member in 1989. These shared characteristics-comparatism, openness to the social sciences, internationalisation of trajectories-found their expression in international scientific dialogue. The post-war global context, characterised by the search for new modes of inter-state regulation, encouraged this process.

The participation of these authors in the international work of scholarly societies such as the IIAS or the SLC offered them concrete access to the understanding of foreign legal systems. In this sense, the SLC and the IIAS opened up valuable perspectives for them in opposition to a French tradition that was, in their view, too little concerned with comparatism. Moreover, while it was difficult to go beyond the horizon of administrative law in the French tradition, the international scholarly arenas provided them with a concrete model of administrative science, coming from countries in which this discipline was less limited by the legal tradition. The example of the American Public Administration is largely taken up by the French authors in their founding textbooks. This reference however remains very general without borrowing specific concepts (Sager et al., 2018: 114). Finally, these scholarly societies also provided them with platforms where they could keep alive the ideal of a scientific and legal internationalism able to overcome the failures of politics and to develop higher legal principles. The 
motto of the SLC reflects this perspective: "Lex multiplex, universa curiositas, jus unum" (Drago 1969c: 314-315) [the legislation is diverse, the thirst for knowledge is universal, the law is one].

\section{The comparative ideal in the service of peace}

The ambition of administrative science was, on the one hand, to contribute to a better control of administrative power and, on the other hand, to counterbalance the power of nation states by setting up mechanisms for international dialogue.

Administrative science, legal universalism and fundamental rights

The personal investment of René Cassin, Roland Drago and Georges Langrod in international scholarly societies reflects the congruence of their political project in favour of a peaceful world order, and of the scientific project in which these aspirations were transposed.

Holding a doctorate in legal, economic and political sciences, René Cassin (1887-1976) was enlisted in 1914, then wounded on the battlefield and discharged in 1916. Thereafter, he taught law at several French universities. During the inter-war period, his research focused, among others, on inter-state relations (Cassin, 1939) and on the League of Nations (Cassin, 1927), where he represented France from 1924 to 1938. During the Second World War, he joined General de Gaulle in England, then participated in the creation of UNESCO with the Allied Powers in 1944. He was the French UNESCO representative between 1945 and 1952. He also represented France at the United Nations between 1946 and 1958. Finally, he was involved in the drafting of the Universal Declaration of Human Rights of the United Nations Organization (UN) in 1948, and was awarded the Nobel Peace Prize in 1968. Cassin also practised law as Vice-President of the Council of State (1944-1960), member of the Constitutional Council (1960-1971), and President of the European Court of Human Rights (19651968). After the Liberation, he founded, together with other members of the 'judicial resistance', the International Association of Democratic Lawyers, which aimed to strengthen human rights, and served as its first president (Israël, 2005: 412-415). Finally, he participated in the work of the IIAS and founded its French section in 1947. The IFSA was housed in the Council of State, where Cassin served as vicepresident at the time. This affiliation is significant, as the Council of State portrayed itself as a guardian of democracy, ensuring the limitation of state powers.

The career of Roland Drago (1923-2009) - professor of law, economics and social sciences in Parisbears striking similarities to that of Cassin. He was a member of the IFSA, and he also chaired the SLC (1979-1983), after having been its secretary-general (1964-1977). He also served as secretary-general of the International Academy of Comparative Law (1973-2006). His research interests included civil liberties, for instance infringements of liberties in the context of a state of emergency (Drago, 1955) or freedom of the press (Blin et al., 1969). The jurisdictional oversight of the administration was also one of his key topics of interest, as reflected in his Traité de contentieux administratif (Auby and Drago, 1962). His work also covered international organisations and the construction of the European Union (Drago, 1965). Georges Langrod (1903-1990) also participated in the work of the IIAS, the SLC, the International Institute of Political Science and UNESCO. Several turning points in his career contributed to his vocation as a universalist jurist: Starting out as a professor of administrative law and administrative science in Poland during the 1930s, he joined the Polish army during the Second World War before being taken prisoner in Austria between 1940 and 1945. In 1948, he moved to France to become a researcher at the Centre national de la recherche scientifique. He also taught comparative 
law at Saarland University between 1952 and 1959, where he founded the Saarland University Institute for the Comparison and Reconciliation of European Law (Boulet et al., 1980: 463-464).

\section{Internationalising public law and harmonising national systems}

The relationship between national and international law was central in the work of these three authors. René Cassin examined this question early on. Faced with the rise of the Third Reich, he recalls that with the Treaty of Versailles, "(...) the primary concern of the authors of the Covenant of the League of Nations was (...) to organise the settlement of international disputes by peaceful means" (Cassin, 1939: 499). Taking note of "Germany's annihilation of the foundations on which nineteenthcentury international law had been developed", Cassin focused his work on the conditions for a return to peace and the future of inter-state relations. Drago, for his part, believed that comparatism allowed systems to be decompartmentalized: "Thanks to comparative law, we were able to break down barriers between opposing political systems. Analysis [...] has made it possible to identify an immanence between systems where, through dialectic, some could only have seen opposition" (Drago, 1969b: 714). Comparative law represents "the best instrument to reconcile legislations, case law and practices so that a 'Community law' can be created, which would help develop relationships between human beings" (Drago, 1969b: 714, as cited in Sager et al., 2018: 111).

Human rights were also a cornerstone of their action. As states had proven unable to ensure respect for fundamental freedoms, the issue now had to be handled by a higher legal level, based on: "the Charter of Human Rights which will legally 'internationalise' varied and important matters that had been the exclusive jurisdiction of domestic law until now" (Cassin, 1951: 321, as cited in Sager et al, 2018: 107). The proclamation of fundamental individual rights had to prioritize inalienable and universal principles over state interests. The role of the comparative approach in the definition of a supranational legal order lay in the harmonisation of national regimes around these higher principles. States were to enter into certain obligations that had to be formalised in multilateral conventions and legally stipulated (Cassin, 1968: 488). Thus, the implementation of human rights "requires, in the highest degree, the use of the resources of the comparative method" (Cassin, 1968: 449). The purpose of administrative science and comparative law was to bring systems closer together, the unity of law being a factor of cohesion between states (Drago, 1969b). Comparatism is thus placed at the service of universal values around which states must converge. The task of comparatists on the international scene was to promote these principles and pave the way for the different states to adopt the corresponding reforms.

This quest for 'social commonalities was to ultimately lead to "social universalism (...) a concordance and mutual understanding of existing systems" (Langrod, 1952: $35,29)$. These considerations were also on the agenda of UNESCO: "The constitutive act of the U.N.E.S.C.O. (...) advocates the mutual knowledge and understanding of nations through the development, on a global scale, of the study of foreign law and through the use of the comparative method. (...) although comparative law continues to be neglected in university education, a new era seems to be dawning" (Langrod, 1957: 353-354). In the future supranational system, administration was to gain importance over politics:

"Thanks to this institutionalised plan to bring countries together, (...) we obtain an ideal field for constant comparisons. (...) This seems to be particularly important for the Administration, 
since-in the face of a series of political failures of international bodies-we can observe the unquestionable success of these bodies on various administrative levels" (Langrod, 1952: 34).

Administrative science was also used in international technical assistance. For example, during a reform mission in Greece on behalf of the Organisation for Economic Co-operation and Development, Langrod experimented some administrative science instruments he had developed. Describing Greece as "deeply caught in a secular routine" (Langrod, 1965: 67), the author stressed that it was hardly possible, "in a developing country, (...) to skip the intermediate stages and directly apply measures which, elsewhere, had resulted from a long evolution" (Langrod, 1965: 67). In this case, the global convergence of systems looks more like the export of legal-administrative techniques, in a perspective marked by developmentalism. The concrete implementation of the universalist ambition in a context of asymmetrical international exchanges thus reveals the contradictions and limits of the project.

\section{Discussion: of the quest for a new administrative legitimacy}

The history of the founders of French administrative science sheds light on the reasons for the creation of this new discipline. Affected by the war, driven by a universalist project and a comparative legal ethos, they initiated a project aimed at reforming the control of administrative action. Some of them were members of the Council of State: reviewing the legality of administrative action was a major concern for them at national level. At the international level, they focused on the establishment of a supranational system and the diffusion of fundamental legal and administrative principles. The national and international aspects of their project had in common the desire to limit state power. In this context, administrative science was seen as a means of studying the concrete reality of state action in the changing post-war situation. Finally, administrative science also allowed to deal with the criticisms against administrative law, and to keep control over administrative studies against the competing approaches emerging at the time. In doing so, the first generation of administrative science authors perpetuate a French specificity - the tendency of the 'state bourgeoisie'-i.e., senior officials - to monopolise the study of administration (Eymeri-Douzans and Bouckaert, 2013: 13-14).

Administrative science thus opened itself to extra-legal considerations. These authors did not perceive their search for new safeguards regarding the legality of administrative action as an attack on the power of the administration. On the contrary, a stronger control over administration legitimises the scope of its powers, in a new combination of legitimacy by efficiency (extension of the scope of administrative intervention in the post-war decades) and legitimacy by legality (new guarantees of citizen protection associated with these changes and strengthening of jurisdictional control over administration by the Council of State) (Rosser and Mavrot, 2017). However, sociology and political science increasingly took over the study of administration after the war (Bongrand et al., 2012: 12), and tended to overtake the more juridical type of administrative science. The latter did not manage to professionalise and specialise as political science did, nor did it succeed in creating a sufficient audience for its research and teaching activities. Moreover, juridical administrative science strongly remained in the realm of administrative law. Finally, administrative research and teaching continued to be were fragmented between the law faculties, the ENA (École nationale d'administration) and the Institutes of Political Studies (IEP) (Sadran, 1999).

Nevertheless, any hasty interpretation of this scientific project as a failure should be avoided. The authors of administrative science undeniably succeeded in drawing attention to the need for a non- 
exclusively legal approach to administration; they created important institutions that have lasted in the French academic world, such as the CRA or the CERSA. Moreover, their comparative work undoubtedly gave a new impetus to administrative law, in the context of the post-war multilateral order. In the end, however, the fragmented development of this science shows the difficulties it had to turn into a discipline on its own. French administrative science struggled to find organisations in which to institutionalise, and often remained more of a program than an actual science. Finally, this project did not lack ambiguities at the time of the emergence of the Cold War and the confrontation between the blocs, although it should be understood in the light of the immediate post-World War II context. The search for a convergence around universal administrative principles was sometimes more of an export of administrative models - which can be described as a subjective universality (Casanova, 1999, as cited in Saunier, 2003: 241) - than a real transnational dialogue.

\section{Conclusion}

Some lessons can be drawn from the history of this attempt to create a new scientific discipline, which relate to the changes in the constitutional order in the post-war period. Firstly, it reflects the intense debates around administration and its role as a state power and as a key instrument of social regulation. The reconceptualisation of administration in the immediate afterwar arises inevitably from the experience of totalitarianism. The Second World War dramatically showed the consequences of a lack of checks and balances against the executive power. The comparative administrative science promoted by these French jurists is also part of a more general context aimed at limiting the power of states and at establishing a supranational legal community.

Secondly the history of French administrative science highlights the importance of international exchanges in the process of scientific innovation. After the war, international scientific dialogue was reestablished with the reactivation of platforms such as the IIAS and the SLC. French administrative science was founded in this context of internationalisation, which was favourable to a broadening of the perspective on administration beyond the legal approach. This reflects a shift from the 19th century 'sciences of government' as 'scientific knowledge (...) at the service of rapidly expanding national states', to sciences that are embedded in a complex web of transnational-and asymmetrical-relations (Heilbron et al., 2009: 121-123, 139). Initiatives aimed at re-establishing a dialogue between states had strong affinities with the comparative administrative science project and its ideology of administrative convergence. Thirdly and on the contrary, the history of administrative science also highlights the strength of national traditions in the face of scientific innovation attempts. In the case of France, administrative science was caught between an administrative law focused on the study of litigation and the national framework on the one hand, and emerging social and political sciences on the other hand. Some jurists believed that administrative science discredited the French tradition, since administrative litigation symbolised democracy (Goyard, 1979: 899). Similarly, representatives of the social and political sciences often perceived administrative science as a legal discipline, remaining in the epistemological realm of law (Duran, 1983: 572). These reactions show both the originality and the limits of this scientific project.

Ultimately, French administrative science struggled to be recognised and to establish its own field of study. It however remained scattered among several organisations-law faculties, the Council of State, IFSA, EPHE, Institutes of Political Studies, CRA- and relied more on individuals than on institutionalised positions. The conjunction between an intellectual space and the corresponding socio-professional and 
institutional terrain-a sign of the establishment of a discipline (Fabiani, 2006: 25)-could not be achieved. Beyond the French case, some more general lessons can be drawn from it. The history of French administrative science shows that administrative studies, often considered from the perspective of national traditions, are also influenced by international exchanges; thus, the production of administrative knowledge might be considered in this new light (Sager et al., 2018). Moreover, French administrative science was strongly juridical, due to the specificities of the national context. However, its history is more generally characteristic of the search for a new constitutional order in this period, which took different forms across the countries. Finally, although the institutionalisation of administrative science failed in France, its promoters nevertheless succeeded in highlighting the necessity of understanding the concrete functioning of the administration, to be able to better control this state power.

\section{Bibliographical references}

Auby JM et Drago R (1962) Traité de contentieux administratif. Paris : Librairie générale de droit et de jurisprudence.

Auby JM, Bandet P, Boulet L et al. (eds) (1966) Traité de science administrative. Paris, La Haye : Mouton. Baruch M et Duclert V (2003) Administrateurs et administrations sous la IV République : une histoire politique. Revue française d'administration publique 4(108) : 501-519.

Blin H, Chavanne A et Drago R (1969) Traité du droit de la presse : ancien code de la presse de Barbier. Paris : Librairies Techniques.

Blondiaux L (2002) Pour une histoire sociale de la science politique. In : Déloye Y et Voutat B (eds) Faire de la science politique. Pour une analyse socio-historique du politique. Paris : Belin, pp. 45-63.

Bongrand P, Gervais J et Payre R (2012) Les savoirs de gouvernement à la frontière entre "administration" et "politique". Gouvernement et action publique 4(4) : 7-20.

Boulet L, Dupuis G, Menier J et al. (eds) (1980) Science et action administratives : mélanges Georges Langrod. Paris : Les Editions d'Organisation.

Braibant G (1969) Introduction. Cahiers de l'Institut français des sciences administratives 3 : 5-9.

Braibant G, Questiaux N et Wiener C (1973) Le contrôle de l'administration et la protection des citoyens : étude comparative. Paris : Cujas.

Casanova P (1999) La République mondiale des lettres. Paris : Seuil.

Cassin R (1927) La France, la Société des Nations et les puissances. Une année de vie internationale (1926-1927). Paris : éditions de l’Unions Fédérale.

Cassin R (1939) L'évolution des conditions juridiques de la guerre économique. Politique étrangère 4(5) : 488-512. 
Cassin R (1951) [réédition 1993] Les droits de l'Homme. In : Académie de droit international et Dotation Carnegie pour la paix internationale (ed) Recueil des cours 1951 II, tome 79. Norwell MA : Kluwer Academic Publishers, 131p.

Cassin R (1967) Henry Puget. Revue internationale de droit comparé 19(2) : 486-488.

Cassin R (1968) Droits de l'Homme et méthode comparative. Revue internationale de droit comparé 20(3) : 449-492.

Chevallier J (1986) Science administrative. Paris : Presses Universitaires de France.

Crozier M. (1979) On ne change pas la société par décret. Paris : B. Grasset.

Debbasch C (1970) H. Puget, Les institutions administratives étrangères. Revue internationale de droit comparé 22(2) : 436-437.

Debbasch C (1972) Science administrative : administration publique. Paris : Dalloz.

Debbasch C (1978) Institutions et droit administratifs. L'action et le contrôle de l'administration. Paris : Presses Universitaires de France.

Drago R (1955) L'Etat d'urgence (lois des 3 avril et 7 août 1955) et les libertés publiques. Revue du droit public juillet/septembre : 670-705.

Drago R (1965) Activité de la Société au cours de l'année 1964. Revue internationale de droit comparé 17(1) : 139-140.

Drago R (1969a) La recherche administrative dans les facultés de droit. Cahiers de l'Institut français des sciences administratives $3: 11-19$.

Drago R (1969b) Allocution de M. Roland Drago. Revue internationale de droit comparé 21(4) : 713715.

Drago R (1969c) Allocution de M. Roland Drago. Revue internationale de droit comparé 21(2) : 311319.

Druesne G (1978) B. Pacteau, Le juge de l'excès de pouvoir et les motifs de l'acte administratif. Revue internationale de droit comparé 30(3) : 914-916.

Duran P (1983) Ashford Douglas E., British dogmatism and French pragmatism, central-local policy making in the Welfare State. Revue française de sociologie 24(3) : 565-572.

Eymeri-Douzans JM et Bouckaert G (eds) (2013) La France et ses administrations. Un état des savoirs. Bruxelles : Bruylant, GEAP/IISA.

Fabiani JL (2006) À quoi sert la notion de discipline ? In : Boutier J, Passeron JC et Revel J (eds) Qu'estce qu'une discipline ? Paris : Éditions de l'École des Hautes Études en Sciences Sociales, pp. 11-34. 
Gottraux P, Schorderet PA et Voutat B (2004) L'émergence d'une discipline scientifique. La création de I'Association Suisse de Science Politique (1951-1959). Swiss Political Science Review 10(1) : 1-28.

Gournay B (1962) Les administrations verticales. Revue économique 13(6) : 920-929.

Gournay B (1966) Introduction à la science administrative: les administrations publiques dans les sociétés contemporaines. Paris : Armand Colin.

Goyard C (1979) J. Chevallier et D. Loschak - Science administrative. Revue internationale de droit comparé 31(4) 898-901.

Heilbron J, Guilhot N et Jeanpierre L (2009) Vers une histoire transnationale des sciences sociales. Sociétés contemporaines $1(73)$ : 121-145.

Ihl O et Kaluszynski M (2002) Pour une sociologie historique des sciences de gouvernement. Revue française d'administration publique 2(102) : 229-243.

Ihl O, Kaluszynski M et Pollet G (2003) Introduction. Pour une socio-histoire des sciences de gouvernement. In : Ihl O, Kaluszynski $\mathrm{M}$ et Pollet $\mathrm{G}$ (eds) Les sciences de gouvernement. Paris : Economica, pp. 1-21.

Israël L (2005) Robes noires, années sombres : avocats et magistrats en résistance pendant la Seconde Guerre mondiale. Paris : Fayard.

Langrod G (1950) Political Science in Poland. In : Unesco (ed) Contemporary Political Science. A Survey of Methods, Research and Teaching. Paris: Unesco, pp. 178-195.

Langrod G (1952) Méthode comparative et sciences administratives. Annales Universitatis Saraviensis I(1) : 25-36.

Langrod G (1954) La science et l'enseignement de l'administration publique aux États-Unis. Paris: Armand Colin.

Langrod G (1957) Quelques réflexions méthodologiques sur la comparaison en science juridique. Revue internationale de droit comparé 9(2) : 353-369.

Langrod G (1959) Molitor (André) - Administration publique (Les Sciences sociales dans l'enseignement supérieur) ; Rapport élaboré pour l'Unesco à la demande de l'Institut international des Sciences administratives (compte-rendu). Revue internationale de droit comparé 11(3) : 620-622.

Langrod G (1960) La procédure administrative non contentieuse. Luxembourg: Cours de la faculté Internationale de droit comparé, $2^{\text {ème }}$ semestre $n^{\circ}$ A 250 , session d'été.

Langrod G (1965) Réorganisation de la fonction publique en Grèce. Paris : Publications de l'Organisation de Coopération et de Développement Economiques. 
Mavrot C (2015) The Dawn of French Administrative Science (1945-1970): A Renewed Conception of the Public Servant. In : Sager F et Overeem P (eds) The European Public Servant: A Shared Administrative Identity? Colchester: ECPR Press, pp. 155-173.

Payre R (2002) The Science that Never Was: 'Communal Science' in France, 1913-1949. Contemporary European History 11(4): 529-547.

Payre R (2006) L'Etat vu d'en haut : la réforme de l'Etat au sein des espaces internationaux de la science administrative dans l'entre-deux-guerres. Revue française d'administration publique 4(120) : 651-666.

Payre R et Vanneuville R (2003) "Les habits savants du politique". Des mises en forme savante du politique à la formation de sciences de gouvernement. Revue française de science politique 53(2) : 195200.

Pinto L (1995) Les neveux de Zarathoustra. La réception de Nietzsche en France. Paris : Seuil.

Puget H (1950) Le Centre de Recherches Administratives. La Revue administrative 3(13) : 107-110.

Puget H (1951) L'Administration française et les organismes internationaux. La Revue administrative 4(19) : 6-16.

Puget $\mathrm{H}$ (1961) Essai de bibliographie des principaux ouvrages de droit public (droit public général, droit constitutionnel, droit administratif), de science politique et de science administrative qui ont paru hors de France de 1945 à 1958. Paris : Éditions de l'épargne.

Rosser C, Mavrot C (2017) Questioning the Constitutional Order: A Comparison of the French and the U.S. Politics-Administration Dichotomy Controversies After World War II. American Review of Public Administration 47(7) : 737-751.

Sadran P (1999) Public Administration Programmes in France. In : Verheijen T et Connaughton B (eds) Higher Education Programmes in Public Administration: Ready for the Challenge of Europeanisation? University of Limerick: Centre for European Studies.

Sager F, Rosser C, Mavrot C, Hurni P (2018) A Transatlantic History of Public Administration: Analyzing the USA, Germany and France. Cheltenham : Edward Elgar.

Saunier PY (2003) Administrer le monde ? Les fondations philanthropiques et la Public Administration aux Etats-Unis (1930-1960). Revue française de science politique 53(2) : 237-255.

Saunier PY (2004) Paris in the Springtime : un voyage de sciences sociales en 1929. Revue d'histoire des sciences humaines 2(11) : 127-156.

Timsit G (2008) Hommage à Guy Braibant. Revue internationale des sciences administratives 74(3): 367-370.

Vanneuville R (2003) Le droit administratif comme savoir de gouvernement ? " René Worms et le Conseil d'Etat devant l'académie des sciences morales et politiques au début du $20^{\text {ème }}$ siècle. Revue française de science politique 53(2) : 219-235. 
Biography: Céline Mavrot is a postdoctoral researcher at the University of Bern and a visiting researcher at the University of California - Los Angeles (UCLA). She completed her PhD on the history of the French administrative sciences. She is particularly interested in the reconstruction of a constitutional order in the post-World War II period and the establishment of new checks and balances between the executive, legislative and judicial powers. Her comparative work on the subject has been published, among others, in The American Review of Public Administration, with Christian Rosser, as well as in Public Administration and in the book A Transatlantic History of Public Administration: Analyzing the USA, Germany and France (Edward Elgar), with Fritz Sager, Christian Rosser and Pascal Hurni.

Acknowledgements: The author would like to thank Fritz Sager and Jean-Michel Eymeri-Douzans, the anonymous reviewers, as well as Pierre-Antoine Schorderet, Claire-Lise Debluë and David Pichonnaz for their valuable comments on an earlier version of this text. The views expressed in this article are solely those of its author.

Funding: This article was written as part of the project 'The Transatlantic Transfer of Administrative Ideas in the 20th Century', funded by the Swiss National Science Foundation (project number PDFM $119458 / 1)$. 